\title{
The Effectiveness of the SERASI Intervention Program in Improving Parents' Positive Attitudes towards Students with Disabilities
}

\author{
Farida Aini ${ }^{\mathrm{a}}$ and Farida Kurniawati ${ }^{\mathrm{b}}$
}

${ }^{a}$ Faculty of Psychology, Universitas Indonesia, Depok, Indonesia, ${ }^{b}$ Department of Educational Psychology, Faculty of Psychology, Universitas Indonesia, Depok, Indonesia

*Corresponding Authors:

Farida Kurniawati

Department of Educational Psychology

Faculty of Psychology, Universitas Indonesia

J1. Lkr. Kampus Raya, Depok, Jawa Barat

Indonesia, 16424

Tel.: +62 217270004

Email address: farida1@ui.ac.id / fafadana@gmail.com 


\title{
The Effectiveness of the SERASI Intervention Program in Improving Parents' Positive Attitudes towards Students with Disabilities
}

\begin{abstract}
Improving parents' positive attitudes towards students with disabilities is the first step in increasing their role in inclusive education. The SERASI (Sekolah Ramah Inklusi) intervention program was designed to improve the attitudes of parents of general education students towards students with disabilities in inclusive primary schools. This study aims to examine the SERASI intervention program's effectiveness. Twenty-three mothers of general education students from inclusive schools participated in this study. Before and after receiving two days of training, the parents filled out the PATCH questionnaire developed by Rosenbaum, Armstrong, and King (1987) in order to measure their attitudes. The results showed a significant increase in the parents' attitude scores after completing the intervention program. The pre-test scores were $\mathrm{M}=77.35$ and $\mathrm{SD}=6.766$, and the post-test scores were $\mathrm{M}=83.65$ and $\mathrm{SD}=9.393(\mathrm{t}(22)=-5.182, \mathrm{p}=0.000)$. Based on these results, we conclude that the SERASI intervention program appears to be generally effective in improving parents' attitude scores, suggesting that the program could improve parents' attitudes towards students with disabilities. We suggest further studies, such as a measurement of the attitudes of general education students towards students with disabilities prior to and following their parents' participation in the SERASI intervention program.
\end{abstract}

Keywords: Inclusive education, disabilities, attitudes, parents, SERASI Intervention Program

\section{Introduction}

The National Education System Law No. 20/2003 states that every citizen has the right to an education, including children with disabilities. The Minister of National Education Regulation (Permendiknas) No. 70/2009 confirms that students with disabilities have the right to attend traditional schools. This opportunity is based on the differences and characteristics of each student and is known as "inclusive education." "Inclusive education" refers to the implementation of education for both general education students and students with disabilities in traditional schools. This program aims to increase children's understanding of diversity and tolerance. Through it, general education students can learn that different characteristics are an opportunity to enrich and enhance learning rather than perceiving them as problems. Students with disabilities also have a chance to develop their potential (UNICEF, 2007). De Boer, Pijl and Minnaert (2014) have stated that inclusive education programs proved effective in reducing discrimination, creating openness, building an inclusive society, and providing education to all children. Hallahan and Kauffman (2006) have stated that inclusive education is an educational process that provides opportunities for all students, including students who have disabilities or talents, to get an equal education. This means that students with disabilities can participate in all or some of the activities in school with general education students.

Inclusive education has many advantages. Evins (2015) has suggested that it impacts not only students with disabilities but all of the students in an inclusive school. General education 
students have the opportunity to learn about tolerance, caring, and empathy for others, while students with disabilities develop emotional and social skills. Building relationships with general education students positively impacts the academic, linguistic, and cognitive development of students with disabilities (Kiuuru, Aunola, Poskiparta, Ahonen, Poikkeus \& Nurmi, 2015; Avcloglu, 2017). Inclusive education can also enhance peer acceptance for students with disabilities and improve their confidence. Overall, it benefits both general education students and students with disabilities.

The successful implementation of inclusive education involves various parties, one of them being parents. Parents in Indonesia are often involved in school committees. They are regulated by the Minister of Education and Culture No. 75/2016. School committees bring together parents, school communities, and community leaders to improve education services. This trend indicates that Indonesian parents actively participate in the education process. As a part of the school support system, they can help students with disabilities in developing their social and emotional skills (Ary, 2017; Leyser \& Kirk, 2004). Parents also have an important role in the success of inclusive education through their involvement in school activities. This is supported by research that proves that parental involvement is one of the crucial success factors in inclusive education (Leyser \& Kirk, 2004; Neely \& Dia, 2008; Beauregard, 2011; De Boer, Pij1 $\&$ Minnaert, 2014; Neyadi, 2015; Ary, 2017). Parents who have a positive perception of inclusive education provide support for schools in developing programs related to students with disabilities (Narumanchi \& Bhargava, 2011). Beauregard (2011) suggests that parental involvement in inclusive education is very comprehensive for parents of students with disabilities as well as parents of general education students.

Unfortunately, parental involvement in the implementation of inclusive education in Indonesia has not been optimal. One of the studies conducted by Tarnoto (2016) involving 112 teachers in 18 inclusive elementary schools in Yogyakarta reveals that the teachers think that only a small percentage $(3.64 \%)$ of parents of general education students have tolerance towards students with disabilities. Most parents lack understanding of and knowledge about appropriate responses towards students with disabilities. Mujito, Director of Special Education at the Ministry of National Education 2018, stated that most parents of general education students reject students with disabilities because the parents believe that general education schools became Special Schools when they admitted students with disabilities. This is noteworthy, because acceptance by all stakeholders is an important factor in the success of educating students with disabilities (Susanti, 2016).

Research by Tafa and Manolitsis (2003) involving 290 parents of general education students illustrated that increased interaction with students with disabilities led to more positive attitudes towards them. De Boer and Munde (2014) have stated that a lack of experience with students with disabilities correlates to negative attitudes towards them among parents. Research conducted by Neyadi (2005) has shown the differences in attitude towards students with disabilities among parents of general education students and parents of students with disabilities. For example, parents who have children with physical disabilities do not consider these disabilities as barriers to education. However, parents of general education students sometimes 
believe that the presence of students with physical disabilities may affect the education of students without disabilities. Nevertheless, most parents of general education students have a positive attitude towards inclusive education.

Here, the term attitude is defined as "a disposition to respond favorably or unfavorably to an object, person, institution, or event." Attitude has three components: cognitive, affective, and psychomotor (Ajzen, 2005). In this study, the definition of attitude refers to the definition proposed by Triandis (cited in De Boer \& Munde, 2014), who described three components of attitudes towards students with disabilities: 1) the cognitive component, referring to knowledge and understanding towards students with disabilities, 2) the affective component, referring to empathy towards students with disabilities, and 3) the behavioral intent component, referring to the enhanced self-efficacy of parents towards students with disabilities both in academic and non-academic fields.

According to Oskamp and Schultz (2005), attitudes can be formed through direct and indirect, or vicarious, experience. Experiencing direct interaction with students with disabilities in school, especially for parents of general education students, affects their attitude towards students with disabilities. A literature review by De Boer, Pijl and Minnaert (2014) shows that parents of general education students who have direct experience with inclusive education and with students with disabilities have a more positive attitude than those who lack this experience. Parents who have this positive attitude are able to pass it on to their general education children, who interact with students with disabilities. It indicates acceptance, support, and awareness in helping students with disabilities (Narumanchi \& Bhargava, 2011). We can conclude that fostering a positive attitude towards students with disabilities among parents of general education students is the first step in increasing parental involvement in inclusive education implementation.

Research conducted by Clore and Jeffrey (cited in Watts, 1984, p.41) shown that interventions through role play and vicarious experience are effective in improving positive attitudes towards students with disabilities. According to Towner (1980), there are ten techniques for changing attitudes: repetition, information-giving, role play, social contact, direct experience, face-to-face contact through media, group discussion, active participation, positive reinforcement of observation, and persuasive communication. In this study, the interventions applied several techniques to improve positive attitudes, including information-giving, role play, group discussion, and active participation.

Previous research has emphasized the intervention of parents of students with disabilities. For example, research involving children with autism and their parents and using the message intervention has been carried out by Cullen-Powell, Barlow, and Cushway (2005). They found that physical and emotional closeness increased after the participants attended a 16-week intervention session. Sjarif (2012) has conducted a study on solution-focused approach intervention that proved effective in helping parents overcome problems related to caring for children with Autism Spectrum Disorder. The participants in this study were three mothers who had children with Autism Spectrum Disorder. 
In our study, intervention focuses more on parents of general education students. The SERASI (Sekolah Ramah Inklusi) intervention program was developed to improve parents' attitudes towards students with disabilities. This program focuses on three components of attitudes towards children with disabilities, cognitive, affective, and behavioral intent. It is based on the theory of attitude developed by Triandis (cited in De Boer \& Munde, 2014). Our intervention was held over a two-day training program. Participants had the opportunity to participate actively during the training process. Training proved effective in the adult learning process because it implemented the principles of experiential learning (Kolb in Laird, Holton, \& Naquin, 2003). Our study aimed to examine the effectiveness of the SERASI intervention program in increasing parents' scores in positive attitude towards students with disabilities.

\section{Methods}

\section{Participants}

Participants were selected by a purposive sampling technique. They were parents of general education students in inclusive primary schools without students with disabilities. Twentythree mothers were involved in this research. The participants were sorted by grade level: parents of first grade students 39\% $(n=9)$, parents of second grade students $17 \%(n=4)$, parents of third grade students $22 \%(n=5)$, parents of fourth grade students $13 \%(n=3)$, and parents of fifth grade students $9 \%(n=2)$. The youngest participant was 30 years old and the oldest was 50 years old $(M=38)$. Most of the participants $(78 \%)$ had a senior high school education.

\section{Design}

A quasi-experimental research design was conducted in this study to evaluate the effect of independent variables on the dependent variable. The study included one group pre- and posttest to compare the scores of the participants before and after intervention.

The study began with a literature study on the attitudes of parents towards students with disabilities. The training module was designed according to the three components of attitude related to students with disabilities, cognitive, affective, and behavioral intent. After obtaining approval from an inclusive primary school principal, the researcher gave informed consent to all prospective participants. Thirty-one participants returned the completed informed consent. Twenty-seven parents attended the first-day training. Two of the parents have a child with disabilities, so they were excluded on the basis of not meeting the participant criteria. On the second day of training, two participants were not present. All in all, twenty-three participants completed the full training session and met the criteria for participants.

The researcher developed a follow-up action plan to measure the parents' attitudes three months after training.

\section{Intervention}

The intervention was based on the three components of attitude and designed by integrating disability awareness, empathy, and self-efficacy in helping students with disabilities. Seven 
training sessions were designed: 1) one pre-intervention session, including a pre-test stage, 2) five intervention sessions consisting of inclusive education, disability awareness, communication strategy for students with disabilities (cognitive), empathy for students with disabilities (affective), and self-efficacy in helping students with disabilities (behavioral intent), and 3) one post-intervention session, involving a post-test and a general evaluation of the training implementation.

The training was held in an inclusive elementary school teacher room. The training venue provided adequate facilities such as a whiteboard, in focus, speaker etc. The training took place for five hours each day and lasted for two days. On the first day, the training ran from 9:00 a.m. to 2:00 p.m., and on the second day, the training ran from 8:00 a.m. to 1:00 p.m.

Two videos about the implementation of inclusive education in several countries, including Indonesia, were shown, as well as a video about individuals with special needs who have achieved success in life. In addition to this, a mother of a student with a disability who attended general education school was invited to share her experiences. This was a part of the empathy session. Participants were encouraged to have empathy towards students with disabilities by sharing their direct experiences. Moreover, participants had a chance to create an action plan to help students with disabilities, such as inviting them to Independence Day activities. Participants also completed homework by discussing their lessons with their children. They were also asked to answer questions about their children's interaction with their friends with disabilities and to discuss an action plan to help students with disabilities.

\section{Variable}

The variable measured in this study was the attitude of parents of general education students towards students with disabilities. Interventions were given over two days of training consisting of seven sessions.

\section{Data Collection}

Parents' attitudes towards students with disabilities were measured using the PATCH (Parental Attitudes Towards Children with Handicapped) scale developed by Rosenbaum, Armstrong, and King (1987). The PATCH scale consists of 30 statements that are balanced between the positive and the negative. The PATCH scale is a Likert scale with five-answer choices ranging from "strongly disagree" to "strongly agree." The PATCH scale covers the three dimensions of attitudes, and each dimension consists of 10 items.

The PATCH scale was adapted to a Bahasa Indonesia version to meet the needs of the local community. Some stages were conducted during the process of adaptation and validation. This began with a translation process, an expert review, and first implementation. The PATCH Bahasa Indonesia version scale was assigned to 310 parents of general education students in four inclusive elementary schools in Jakarta and Depok. A confirmatory factor analysis resulted in 26 significant items with factor loading range $0.032-0.92$ and Cronbach $\alpha=0.917$. The PATCH Bahasa Indonesia version consists of seven cognitive dimension items, nine affective dimension items, and ten behavioral intent dimension items. It uses a Likert scale with four 
answer choices: strongly agree, agree, disagree, and strongly disagree. All participants filled out the PATCH scale before and after training. Moreover, participants answered 15 multiple-choice questions about the training material before and after training. Finally, the participants were asked to give feedback about the training implementation in the post-test session.

\section{Statistical Analysis}

The data was analyzed using the $t$-test to compare the total score in the pre- and post-test stages. Paired simple $T$-test analysis was used to compare the score for each dimension of attitude between the pre- and post-test score.

\section{Results}

The PATCH Bahasa Indonesia version showed an increase in the total attitude score and the score of each dimension in the post-test stage.

\section{Pre-test to Post-test Comparisons}

Total score in the post-test stage is higher than the total score in the pre-test stage. The score of participants' attitudes towards students with disabilities increased after participating in the intervention. The paired simple $T$-test showed a significant increase between the total pre-test scores $(M=77.35, S D=6.766)$ and the post-test scores $(M=83.65, \mathrm{~S} D=9.393), t(22)=-5,182$, $p=0,000$. These scores indicate that the SERASI intervention program is effective in increasing a positive attitude among parents towards students with disabilities.

\section{Cognitive Dimension}

The paired simple $T$-test on the cognitive dimension showed a significant increase in scores between the pre-test scores $(M=21.00, S D=2.780)$ and the post-test scores $(M=22.61, S D=$ $3.144), t(22)=-3.869, p=0.001$. This score demonstrates that the parents' knowledge on inclusive education, their role in implementing inclusive education, types of disabilities, and understanding towards students with disabilities increased after training.

\section{Affective Dimension}

The paired simple $T$-test on the affective dimension showed a significant increase in scores between the pre-test score $(M=26.48, S D=2.644)$ and the post-test score $(M=28.83, S D=$ $3.353), t(22)=-4.267, p=0.000$. This score illustrates the increase of the participants' emotional responses to students with disabilities in the post-test stage.

\section{Behavioral Intent Dimension}

The paired simple $T$-test on behavioral intent dimensions showed a significant increase in scores between the pre-test scores $(M=29.87, S D=2,564)$ and the post-test scores $(M=32.22, S D=$ $3,861), t(22)=-4.134, p=0.000$. This score shows the increase in the participants' self-efficacy in providing assistance to students with disabilities after training. 


\section{Training Material}

Our research also found that the score of participants' understanding of the training material increased. Participants were able to answer questions correctly with a score of $74 \%$ in the pretest. This score rose to $88 \%$ in the post-test. The score of the participants' understanding of selfefficacy in helping students with disabilities showed the highest increase among all of the scores.

While $59 \%$ of the participants were able to correctly answer questions about inclusive education and disability in the pre-test stage, this increased to $77 \%$ in the post-test stage. While $61 \%$ of the participants correctly answered questions about empathy, this increased to $83 \%$ in the posttest. Participants could answer questions about self-efficacy in helping students with disabilities with a score of $36 \%$ in the pre-test stage. This score rose to $83 \%$ in the post-test stage. These results demonstrate that all of the participants' understanding scores generally increased.

\section{Evaluation for training.}

These other results are related to the evaluation of the implementation of training.

Table 1. Participant's Evaluations

\begin{tabular}{|c|c|c|c|}
\hline Aspect & & $\Lambda$ & $\%$ \\
\hline \multirow[t]{4}{*}{ Training material } & Very useful & 23 & 100 \\
\hline & Useful & 0 & 0 \\
\hline & Not useful & 0 & 0 \\
\hline & Very not useful & 0 & 0 \\
\hline \multirow[t]{4}{*}{ Method } & Very useful & 19 & 82.60 \\
\hline & Useful & 4 & 7.40 \\
\hline & Not useful & 0 & 0 \\
\hline & Very not useful & 0 & 0 \\
\hline \multirow[t]{4}{*}{ Facilitate } & Very useful & 11 & 47.82 \\
\hline & Useful & 12 & 52.18 \\
\hline & Not useful & 0 & 0 \\
\hline & Very not useful & 0 & 0 \\
\hline \multirow[t]{4}{*}{ Facilitator } & Very helpful & 19 & 82.60 \\
\hline & Helpful & 4 & 7.40 \\
\hline & Not helpful & 0 & 0 \\
\hline & Very not helpful & 0 & 0 \\
\hline \multirow[t]{4}{*}{ Duration } & Very enough & 9 & 39.13 \\
\hline & Enough & 11 & 47.83 \\
\hline & Not enough & 2 & 8.69 \\
\hline & Very not enough & 1 & 4.35 \\
\hline
\end{tabular}

Overall, participants had a positive response to the implementation of the intervention program. All of the participants thought that the training material was very useful $(n=23)$. Training was beneficial not only for increasing parental knowledge but also in encouraging participants to 
develop a sense of empathy and self-efficacy to help students with disabilities. The responses of the participants regarding the length of training varied. Some felt that the length of training was sufficient $(n=11)$ while others considered it too short. The participants suggested that the SERASI training for parents be done regularly and to include more participants, including parents of students with disabilities.

\section{Discussion}

Because parents are a part of the school community, their involvement plays an important role in the successful implementation of inclusive education. Previous studies have shown the importance of fostering positive attitudes towards students with disabilities, especially among parents of general education students, as the first step in involving parents in inclusive education (Leyser and Kirk, 2004; Neely and Dia, 2008; Beauregard, 2011; De Boer, Pijl, Minnaert \& Post, 2014; De Boer, Pijl \& Minnaert, 2010, 2014; Neyadi, 2015; Ary, 2017).

This study found that the scores of parents' attitudes both overall and in each dimension of attitude (cognitive, affective, and behavioral intent) increased in the post-test stage. This indicates that the SERASI intervention program is effective at improving parents' attitudes towards students with disabilities. The attitude scores of parents of general education students increased significantly compared to their scores in the pre-test stage. Furthermore, participants did homework by brainstorming with their children at home about students with disabilities. This showed their commitment to transferring their knowledge and influencing their children's attitudes towards students with disabilities.

There are several factors that supported this successful intervention. First, the training module was designed based on the theory of attitude towards students with disabilities developed by Triandis (cited in De Boer \& Munde, 2014) This included 1) the inclusive education, disabilities knowledge, and communication strategy for students with disabilities (cognitive dimension), 2) empathy for students with disabilities (affective dimension), and 3) enhanced self-efficacy in helping students with disabilities (behavioral intent). Participants not only gained knowledge on inclusive education, disabilities, and students with disabilities, but they were also encouraged to have a sense of empathy for these students. In addition to this, participants also had an opportunity to plan activities in order to help students with disabilities. For example, some planned to hold an Independence Day celebration including children with disabilities.

Second, the methods used in the intervention training session included lecture, group discussion, case studies, role play, presentation, and games. This created a more joyful and fun training environment. The participants shared their knowledge and experiences with each other during the training process. Lindsay \& Edwards (2013) have stated that this multi-method intervention is more effective than one-method intervention.

Third, our training applied the principle of experiential learning in some sessions. This aimed to enable participants to share experiences related to their interaction with parents and students with disabilities. Kolb (in Laird, Holton, \& Naquin, 2003) has stated that learning is the process 
of knowledge transformed by experience. Participants not only shared their experiences while interacting with students with disabilities, but they also experienced the presence of a mother with a child with disabilities. Having this mother share her experience of deciding to register her son in a general education school was is an example of the experiential learning method. Her presentation took place in an empathy session. We concluded that it was successful, because the scores for this affective dimension were higher than in the other dimensions. The methods for delivering the training material mostly aligned with the following four steps in the experiential learning cycle: 1) concrete experience, beginning with giving direct or indirect experience related to the topic, 2) observations and reflections from participants on the topic, 3) formation of abstract concepts and generalizations explained by facilitator, and 4) the testing of concepts in new situations.

Finally, the PATCH Bahasa version scale was used in data collection and has the highest reliability (Cronbach $\alpha=0.917$ ) and adequate items to measure parents' attitudes towards students with disabilities. This scale is appropriate for our research questions because it consists of three dimensions of attitude towards students with disabilities, cognitive, affective, and behavioral intent. Boer, Timmerman, Pijl, and Minnaert (2012) have explained that the PATCH scale is the most appropriate instrument for evaluating attitudes towards students with disabilities.

\section{Limitations}

This study did not involve students whose parents participated in the intervention program. We do not have a description of general education students' attitudes towards students with disabilities. We encourage further research to measure students' and parents' attitudes before and after intervention. This will help gauge to what extent intervention affects the improvement of students' attitudes. Regarding the experiential learning cycle implementation in the intervention, researchers suggest applying experiential learning methods to all sessions of intervention. Additionally, the intervention program can be applied not only at the elementary level but also in other levels of education. It aims to implement the SERASI intervention program by involving more parents in inclusive schools.

\section{Implications and Recommendations}

Participants felt that the SERASI training had various advantages. It not only had an impact on increasing parental knowledge on inclusive education and disability, but it also encouraged participants to develop a sense of empathy and self-efficacy in helping students with disabilities. This was proven by the increase in the participants' scores on their understanding of inclusive education and students with disabilities following training. Given that research on intervention for parents of general education students is still very limited, especially in Indonesia, our intervention model can serve as a reference for intervening in order to foster positive parental attitudes. The intervention can be done regularly, especially in an inclusive education setting, by involving more parents of general education students. Future research should focus on measuring students' attitudes before and after their parents' training. Additionally, this intervention could be replicated in other school levels. 


\section{Conclusion}

This study showed that the SERASI intervention program's two-day training was effective in increasing positive attitudes towards students with disabilities among parents of general education students. This is demonstrated by the significant change in pre- and post-test attitude scores. Furthermore, scores for each attitude dimension, including cognitive, affective, and behavioral intent, showed significant increases after participants completed the training. Some of the factors that support the intervention's success are the training module, the various methods, applied experiential learning approaches, and adult education. In addition to this, the necessary factors included adequate training equipment and the proper instrument to measure parents' attitudes toward students with disabilities - one that boasts a high level of reliability and adequate items to evaluate parents' attitude. Evaluations of the training implementation are also beneficial for the participants.

\section{References}

Ajzen, I. (2005). Attitudes, Personality, and Behavior. New York: Open University Press.

Ary, L. S. (2017). Parents' perception of a school-based inclusion program for their children with autism (Doctoral dissertation). Walden University, Minnesota.

Avcloglu, H. (2017). Classroom Teachers Behaviors and Peers Acceptance of Students in Inclusive Classrooms. Educational Sciences: Theory \& Practice, 17(2). 463-492.

Beauregard, F. (2011). Practice adopted by parents of children with dysphasia in inclusive primary school. Exceptionality Education International, 21(3), 15-33.

Cullen-Powell, L. A., Barlow, J. H., \& Cushway, D. (2005). Exploring a massage intervention for parents and their children with autism: the implications for bonding and attachment. Journal of Child Health Care, 4(9), 245-255. doi: 10.1177/1367493505056479.

De Boer, A. A., \& Munde, V. (2014). Parental attitudes towards the inclusion of children with profound intellectual and multiple disabilities in general primary education in the Netherlands. The Journal of Special Education, 49(3), 1-9, doi: 10.1177/0022466914554297.

De Boer, A. A., Pijl, S. J., \& Minnaert, A. (2010). Attitudes of parents towards inclusive education: A review of literature. Journal of Special Needs Education, 25(2), 165-181.

De Boer, A. A., Pijl, S. J., Minnaert, A. \& Post, W. (2014). Evaluating the effectiveness of an intervention program to influence attitudes of students towards peers with disabilities. Journal Autism and Developmental Disorders, 44(3), 572-583. Doi: 10.1007/S10803-013-1908-6

De Boer, A. A., Timmerman, M. Pijl, S. J., \& Minnaert, A. (2012). The Psychometric evaluation of a questionnaire to measure attitudes towards inclusive education. European Journal of Psychology Education, 27(4), 573589. doi: 10.1007/s10212-011-0096-z.

Evins, A. (2015). The effects of inclusion classroom on students with and without developmental disabilities: Teachers' perspectives on the social, emotional, and behavioral development of all students in inclusion classrooms (Doctoral paper). University of Denver, Colorado.

Hallahan, D. P., \& Kauffman, J. M. (2006). Exceptional children: Introduction to special education. Allyn and Bacon.

Kirk, S. A., Gallagher, J., \& Coleman, A. (2009). Educating exceptional children (12th ed) USA: Houghton Mifflin Company.

Kiuuru, N., Aunola, K., Poskiparta, E., Ahonen, T., Poikkeus, A-M., \& Nurmin, J-E. (2015). Positive teacher and peer relations combine to predict primary school student's academic skill development. Developmental Psychology, 51(4), 434-446. doi: 10.1037/a0038911/a0038911

Laird, D., Holton, E. F., \& Naquin, S. S. (2003). Approaches to training and development: revised and updated. Basic Books. 
Leyser, Y., \& Kirk, R. (2004). Evaluating inclusion: An examination of parent views and factors influencing their perspective. International Journal of Disability, Development and Education, 51(3), 271-285. doi: $10.1080 / 1034912042000259233$.

Mujito, (2005). Pendidikan inklusif terhalang penerimaan orang tua murid. Retrieved from https://metro.tempo.co/read/60431/pendidikan-inklusif-terhalang-penerimaan-orang-tua-murid.

Lindsay, S., \& Edwards, A. (2013). A systematic review of disability awareness interventions for children and youth. Disability and Rehabilitation, 35(8), 623-646.

Narumanchi., \& Bhargava, S. (2011). Perceptions of parents of typical children towards inclusive education. Disability, CBR \& Inclusive Development, 22(1), 120-129. doi: 10.5463/DCID.v22i1.10.

Neely, S.L \& Dia, D. A. (2008). Families of children with disabilities: A review of literature and recommendations for intervention. Journal of Early and Intensive Behavior Intervention, 5, 93-107.

Neyadi, M. K. A. (2015). Parents attitude towards inclusion of students with disabilities into the general education classroom (Master thesis). United Emirate Arab University, Al Ain.

Oskamp, S \& Schultz, P. W. (2005). Attitudes and Opinions. New Jersey: Lawrence Erlbaum Associates.

Rosenbaum, P. L., Armstrong, R. W., \& King, S. M. (1987). Parental attitude toward children with handicaps: new perspectives with a new measure. Developmental and Behavioral Pediatric, 8(6), 327-334. http://dx.doi.org/10.1097/00004703-198712000-00004

Sekretariat Negara (2003). Undang-Undang Nomor 20 Tahun 2003 tentang Sistem Pendidikan Nasional. Jakarta: Berita Negara Republik Indonesia.

Sekretariat Negara. (2009). Permendiknas Nomor 70 tahun 2009 tentang Pendidikan Inklusif bagi Peserta Didik yang Memiliki Kelainan dan Memiliki Potensi Kecerdasan dan/atau Bakat Istimewa. Jakarta: Berita Negara Republik Indonesia.

Sekretariat Negara. (2016). Permendikbud Nomor 75 tahun 2016 tentang Komite Sekolah. Jakarta: Berita Negara Republik Indonesia.

Sjarif, D. I. (2012). Intervensi dengan pendekatan solution-focused untuk meningkatkan parental self-efficacy pada orangtua dengan anak autistic spectrum disorder (Unpublished master thesis). Universitas Indonesia, Depok, Indonesia.

Susanti, A. (2016, April 27). Mendidik anak berkebutuhan khusus butuh penerimaan. Retrieved from https://news.okezone.com/read/2016/04/27/65/1373687/mendidik-anak-berkebutuhan-khusus-butuhpenerimaan

Tafa, E., \& Manolitsis, G. (2003). Attitude of Greek parents of typically developing kindergarten children towards inclusive education. European Journal of Special Needs Education, 18(2), 155-171. DOI: $10.1080 / 0885625032000078952$

Tarnoto, N. (2016). Permasalahan-permasalahan yang dihadapi sekolah penyelenggara pendidikan inklusi pada tingkat SD. Humanitas, 13(1), 50-61. ISSN 1693-7236

Towner, A. G. (1980). Modifying attitudes towards the handicapped: a reiew of the literature and methodology. In Jones, R.L, Attitude and attitude change in special education (pp. 223-255). ERIC Publications, Reston. UNICEF. (2007). Promoting the Rights of Children with Dissabilities. UNICEF Innocenti Research Centre.

Watts, W. A. (1984). Theories and Methods. In Jones, R.L, Attitude and attitude change in special education (pp. 41-65). ERIC Publications, Reston. The Council for Exceptional Children. 